\title{
Assessment of the Impacts of Climate Change on Some Hydrological Processes of The Densu River Basin, Ghana
}

\author{
Justice Ankomah-Baffoe ${ }^{1 *}$ \\ David Oscar Yawson ${ }^{2}$ \\ Daniel Okae-Anti ${ }^{3}$
}

\begin{abstract}
Water resources are among the most sensitive sectors to climate change due to their direct relationship with climate variables. The current study used projected climate datasets under two Representative Concentration Pathways (RCPs), 4.5 and 8.5, from the Coupled Model Intercompersion Project Phase 5 (CMIP5), remote sensing and Soil and Water Assessment Tool (SWAT) to estimate the effect of projected climate change on some hydrological processes. We focus on rainfall, water yield, soil water storage and evapotranspiration in the Densu Rvier Basin (DRB) for the 2050s. After calibration and validation of the SWAT model, there was a strong correlation between the simulated and the observed stream discharge coefficient of determination $\left(R^{2}\right)$ of 0.84 and 0.77, and a Nash Sutcliffe Efficiency of 0.76 and 0.70 for calibration and validation, respectively. The results showed an annual mean increase of $2{ }^{\circ} \mathrm{C}$ in temperature, $61 \%$ in evapotranspiration and $20.1 \mathrm{~mm}$ in rainfall amount by the $2050 \mathrm{~s}$ compared to their baseline values. Even though the mean annual soil water storage increases by about $80 \mathrm{~mm}$, water yield declines by about $23 \mathrm{~mm}$ by 2050s. This appears to be due to the disproportionate increase in evapotranspiration compared to increase in rainfall. In conclusion, the DRB is projected to experience an overall reduction in water yield.
\end{abstract}

Keywords: Densu River Basin, climate change, SWAT, hydrological processes, water yield, CMIP5

\footnotetext{
${ }^{1 *}$ CSIR-Soil Research Institute, Accra Centre, Accra, Ghana. *Corresponding author email: jabaffoe@ @ csir.org.gh ${ }^{2}$ University of the West Indies, Centre for Resource Management and Environmental Studies (CERMES) ${ }^{3}$ University of Cape Coast, Department of Soil Science
}

Ghana Journal of Geography Vol. 13 (1), 2021 pages 147-166

https://dx.doi.org/10.4314/gig.v13i1.8 
Ghana Journal of Geography Vol. 13 (1), 2021 pages 147-166

\section{Introduction}

Water is one of the most important natural resources that support human and terrestrial life (Daily, 2003). While the demand for water has increased dramatically in recent years, global environmental change is expected to put additional stresses on water resources. For example, it is projected that two-thirds of the world's population would be under water stress by 2050 (Wallace, 2000; Mekonnen \& Hoekstra, 2016 and Shah et al., 2018). For Africa, climate change is generally expected trigger decreased and more variable rainfall and warmer temperatures. The implications for water resources (quality and quantity) are manifold (Schuol et al., 2008). In Ghana, climate change is being experienced in many parts of the country. Studies show that in the last decade, floods and droughts have become frequent (Asumadu-Sarkodie et al., 2015), and temperature has increased by about $1{ }^{\circ} \mathrm{C}$ across the different agro-ecological zones, while rainfall has reduced or become more variable in some areas (Stanturf et al., 2011; Arndt et al., 2015). Studies on future climate projections across the coastal savannah zone also show an increase in temperature with uncertain rainfall patterns. An assessment of the impact of climate change on water resources (Pra and White Volta basins) shows a reduction in streamflow with a projected decline of 20 to $50 \%$ by the 2050s (Kankam-Yeboah et al., 2013; Awotwi et al., 2015).

The Densu River Basin is noted for its domestic, industrial and agricultural water supply. Nonclimatic drivers such as land degradation, wood harvest, agriculture activities (Ayivor \& Gordon, 2012a) and residential land uses (Yorke \& Margai, 2014) have been reported as threats to the Basin (WRC, 2007). The population density in the basin is about five times larger than the national average of 103 persons per square kilometer (Ghana Statistical Services (GSS, 2012).

Previous studies within the basin have focused on water quality (Karikari \& Ansa-Asare, 2006; Amoako et al., 2010), pesticide residue (Fianko, 2011), groundwater quality (Tay \& Kortatsi, 2008), heavy metals, land use change, runoff, and soil erosion (Ayivor \& Gordon, 2012a and Ashiagbori et al., 2014). Notwithstanding, present changes in temperature, rainfall, evapotranspiration and surface runoff (WRC, 2017) and the rapid changes in land cover and population (Yorke \& Margai, 2014) might threaten the water resource within the basin. However, the impacts of climate change on the hydrological cycle within the basin remain uncertain, which makes adaptation especially challenging. The objective of this study was, therefore, to assess the impact of climate change on some hydrological processes of the Densu 
River Basin (DRB) by the 2050s. Specifically, this study assessed the changes in evapotranspiration, soil storage and the water yield of the DRB under projected climate change.

\section{Materials and Methods}

\section{Study Area}

The Densu River travels from Atiwa-Atwiredu Mountain, which lies between longitudes $0^{\circ} 10$ $-0^{\circ} 37 \mathrm{~W}$ and latitudes $5^{\circ} 30-6^{\circ} 17 \mathrm{~N}$. It covers a distance of about 116 kilometers (Asante et al., 2008) and an area of 2,490 $\mathrm{km}^{2}$. It traverses 11 Local Government Authorities in the Eastern, Central and Greater Accra regions, and enters the sea at Bortianor in the Ga Municipality in the Greater Accra Region. The Odaw and Volta Basins, Birim Basin, Ayensu and Okrudu Basins form catchment boundary with the Densu Basin (WRC, 2017).

The southern part of the basin lies in the Coastal Savannah zone while the northern part lies in the semi-deciduous forest zone (WRC, 2017). The mean annual rainfall of the southern and northern parts of the basin is $846 \mathrm{~mm}$ and $1395 \mathrm{~mm}$ respectively, with major and minor rainfall seasons occurring from May to July and September to November respectively (Karikari \& Ansa-Asare, 2006). The average annual temperature is about $27^{\circ} \mathrm{C}$ and daily sunshine hours of 12 . The hottest periods start from November to April with temperatures around $32{ }^{\circ} \mathrm{C}$ (WRC, 2007). August is the coolest month, with a mean temperature of $23{ }^{\circ} \mathrm{C}$.

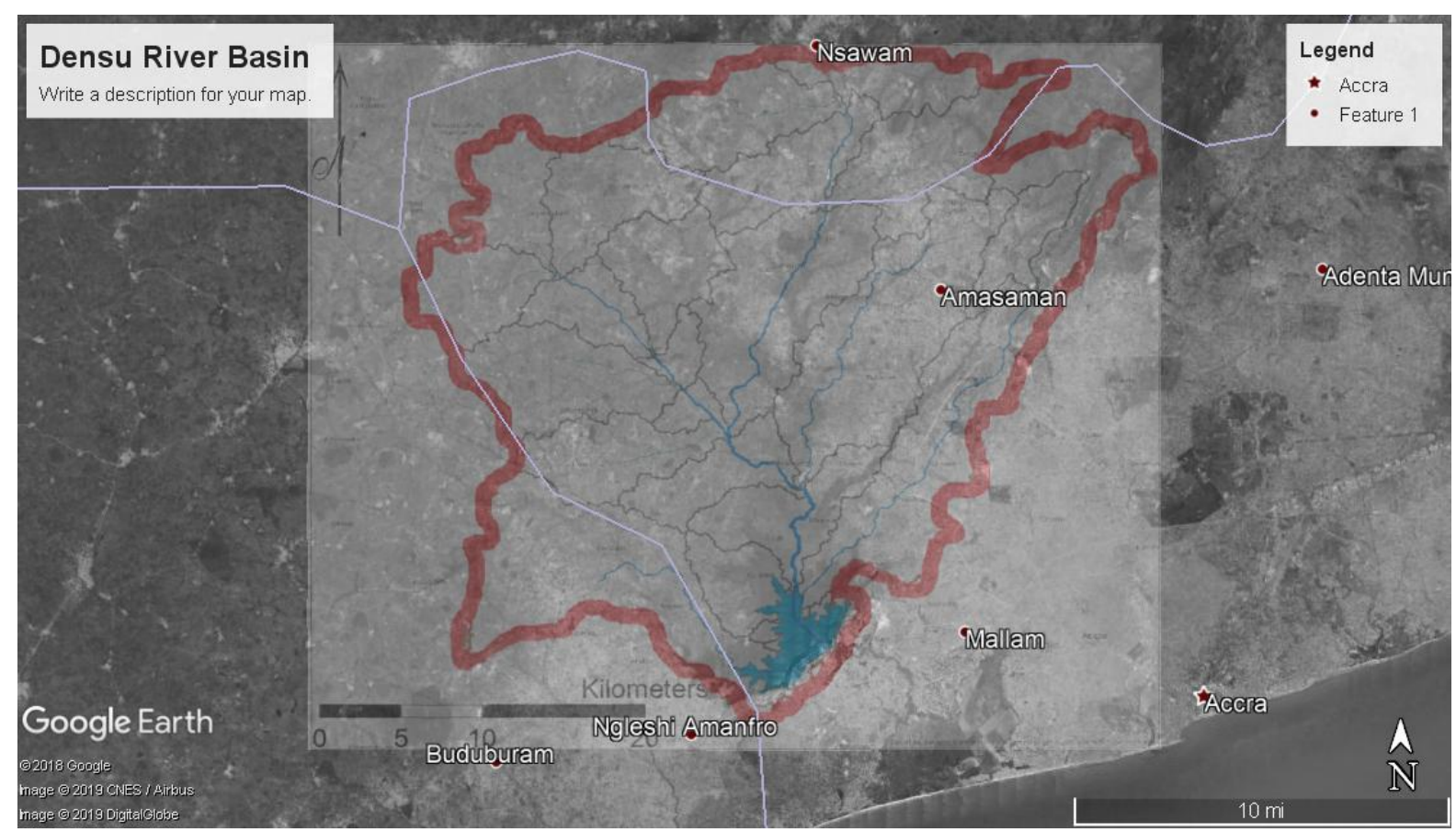

Figure 3: A map of the study area. (Source: basin boundary delineated by authors; base map from Google Earth, 2019). 
Ghana Journal of Geography Vol. 13 (1), 2021 pages 147-166

\section{Modelling Approach}

\section{Description of the Soil and Water Assessment Tool (SWAT) Model}

The Soil and Water Assessment Tool (SWAT) model has proven to be an effective tool for assessing water resource, environmental condition and hydrologic modelling for river basins across the globe (Neitsch et al., 2011). SWAT is a basin-scale, continuous-time hydrological model that operates on a daily time step. The model is physically based, computationally efficient, a continuous simulator over long time periods and has an ArcGIS interface (ArcSWAT) (Gassman et al., 2007).

In SWAT, watersheds are divided into multiple sub basins, which are divided further into Hydrologic Response Units (HRUs) that consist of homogeneous land use, management, and soil characteristics. An HRU represents a percentage of the area covered by a sub-basin and is not identified spatially within a SWAT simulation. The benefit of watershed subdivided into only sub-basins is to dissimilate dominant land use, soil type, and management within the watershed.

The SWAT uses climatic inputs such as daily precipitation, maximum and minimum temperatures, solar radiation data, relative humidity, and wind speed data. These inputs could be generated or obtained from records. Depending on the availability of climatic data, the SWAT model can use the PenmanMonteith, Priestly Taylor, or Hargreaves method in estimating evapotranspiration. The hydrological component of SWAT is driven by the soil water balance of a river basin, which is represented Equation 1 (Neitsch et al., 2011):

$\mathrm{SWt}=\mathrm{SWo}+\sum_{\mathrm{i}=1}^{\mathrm{t}}\left(R_{\text {day }}-Q_{\text {surf }}-\mathrm{E}_{a}-W_{\text {seep }}-Q_{q w}\right)$

where SWt is the soil water content $(\mathrm{mm}), \mathrm{SWo}$ is the initial soil water content on day $\mathrm{i}(\mathrm{mm})$, $\mathrm{t}$ is time (days), $R_{\text {day }}$ is the amount of precipitation on day $\mathrm{i}(\mathrm{mm}), Q_{\text {surf }}$ is the amount of surface runoff on day $\mathrm{i}(\mathrm{mm}), \mathrm{E}_{a}$ is the amount of evapotranspiration on day $\mathrm{i}(\mathrm{mm}), W_{\text {seep }}$ is the amount of water entering the vadose zone from the soil profile on day $\mathrm{i}(\mathrm{mm}), Q_{q w}$ is the amount of return flow on day i $(\mathrm{mm})$.

The Soil Conservation Service (SCS) curve number (CN) is used by SWAT to estimate surface runoff under different land use and soil types (Equation 2) (Neitsch et al., 2011). The SCS curve number equation is:

$$
Q_{\text {surf }}=\frac{\left(R_{\text {day }}-I_{a}\right)^{2}}{\left(R_{\text {day }}-\mathrm{I}+\mathrm{S}\right)}
$$


Where: $Q_{\text {surf }}$ is the accumulated runoff or rainfall excess $(\mathrm{mm}), R_{\text {day }}$ is the rainfall depth for the day $(\mathrm{mm}), I_{a}$ is the initial abstractions which includes surface storage, interception and infiltration prior to runoff $(\mathrm{mm})$ and $\mathrm{S}$ is the retention parameter $(\mathrm{mm})$.

The retention parameter is computed from equation 3 (Neitsch et al., 2011).

$$
S=25.4\left(\frac{1000}{\mathrm{CN}}-10\right)
$$

Where: $\mathrm{CN}$ is the curve number for the day.

In the current study, the Penman-Monteith method was used to compute evapotranspiration in SWAT.

\section{Data}

The ArcSWAT requires both spatial datasets and non-spatial datasets of the watershed being studied. The spatial datasets required were Digital Elevation Model (DEM), land use (LU) and soil types, while the non-spatial dataset included climate data (daily rainfall, minimum and maximum air temperatures, relative humidity, wind speed and solar radiation), and monthly stream discharge (Arnold et al., 2013).

\section{Digital Elevation Model (DEM)}

The DEM for the current study was a 30 m resolution Shuttle Radar Topography Mission (SRTM) DEM downloaded from the United States Geological Survey (USGS) Earth Explorer website. The downloaded DEM was pre-processed in ArcGIS Desktop version 10.3.1 (ESRI $\left.{ }^{\mathrm{TM}}\right)$. The image was scaled, and the area of interest was clipped. The image was then projected to the Universal Transverse Mercator (UTM) zone 30 N, with WGS 84 as the datum and geographic coordinate system.

\section{Land Use (LU)}

A cloudless Landsat 8 (OLI) satellite image over the study area was downloaded from the United States Geological Survey (USGS) website. The Landsat 8 (OLI) image has 11 bands and a $30 \mathrm{~m}$ spatial resolution. The image was acquired on $25^{\text {th }}$ January 2017 . The satellite image was exposed to pre-processing by forming a composite image with a band combination of 6-54 (i.e. near-infrared, red and green bands respectively) from the 11 bands using ArcMap. ISO 
Ghana Journal of Geography Vol. 13 (1), 2021 pages 147-166

Cluster Unsupervised was done to aid in the exploration of the spectral classes in the image. This was then followed with a supervised classification Water bodies, agriculture land, urban/bare lands and vegetation were the main target classes. An accuracy assessment of the classification was done by using random sampling point technique, which was compared to Google Earth image of the study area.

\section{Soil Map}

A digital soil map of the world from the Food and Agriculture Organization of the United Nations (FAO) and UNESCO (Version 3.6) with a scale of 1:5000000 was used for the study. The shapefile for Ghana was selected by attribute query and exported and was defined and transformed from an undefined coordinate to WGS 1984/UTM Zone 30N. A polygon shapefile of the study area with a defined and transformed coordinate was clipped from the Ghana shapefile, exported and transformed to a raster.

\section{Baseline Climate and Discharge Data}

A 30-year climate data, covering the period 1986 - 2015, were obtained from the Ghana Meteorological Agency. The climate data comprised daily rainfall, minimum and maximum air temperature, relative humidity, wind speed and solar radiation. A monthly stream discharge or flow $\left(\mathrm{m}^{3} / \mathrm{sec}\right)$ data for a period of 15 years (1986 to 2000) were obtained from the Hydrological Services Department (Ghana), which operates a number of river gauging stations within the Densu Basin. Missing records in climate data from the stations were filled using the WXGEN weather generator available in SWAT.

\section{Projected Climate Data}

Future climate data were obtained from the Coupled Model Intercomparison Project Phase 5 (CMIP5), which is based on seventeen (17) Atmosphere-Ocean General Circulation Models (AOGCMs) used for the IPCC fifth assessment report (AR5). From this, the future daily climate data for the 2050s time slice was generated using the Marksim weather generator under the Representative Concentration Pathways (RCPs) 4.5 and 8.5, which represent the greenhouse gas concentration trajectories adopted by the IPCC AR5.

The study area was located by latitude, longitude and elevation from the Google map interface of the Marksim weather generator. All the 17 CMIP5 (GCMs) of the interface were selected and an annual daily generated climate data with a replicate each from 2035 to 2065 representing the 2050s time slice was generated for the two emissions scenarios (RCP 4.5 and RCP 8.5). 


\section{SWAT Input Data Pre-processing}

The soil map, which was in a vector shapefile format, was rasterized to allow computational compatibility with the Digital Elevation Model (DEM) and the land use/ land cover map. All the spatial datasets were projected into a common projection system (UTM Zone 30N). The non-spatial datasets were also processed and structured in SWAT-compatible format.

\section{Watershed delineation}

The DEM was used to delineate the watershed parameters: the stream network, watershed area, the outlet and inlet sources, sub-basins and the overall basin. ArcSWAT uses the DEM to create a topographical surface in the basin.

\section{HRU analysis}

The land use and soil data were imported in ArcSWAT under the HRU analysis. ArcSWAT combines the land use, soil and the topographical surface data to create a unique HRU for each sub-basin. In a similar manner, the climate data and locational information of the weather stations were imported in ArcSWAT where the weather data are assigned to the sub-basins.

\section{SWAT simulation}

Simulations were ran from 1986 to 2015 with a three-year warm up period (1986-1989) that allowed the model to stabilise prior to simulation.

\section{Calibration and Validation}

\section{Sequential Uncertainty Fitting 2 (SUFI-2)}

ArcSWAT was used to simulate the stream discharge for Densu Basin. Calibration and validation were done using the Sequential Uncertainty Fitting 2 (SUFI-2) in SWAT. Out of the four methods (GLUE, ParaSol, PSO, and SUFI-2) of analysing the uncertainty in the SWAT model, SUFI-2 method is suggested by Abbaspour et al., (1997); Yang et al., (2008); Khoi \& Thom (2015) as efficient tool for studies on impact of climate change and human activities on water resources.

In SUFI-2, the uncertainty parameters are estimated from all the sources, including climatic data, soil data, land use data, observed discharge data, and parameters. The model uses two statistical factors (p-factor and r-factors) to quantify the fitness between the simulated result and the observed (measured stream flow or discharge). The p-factor is expressed as the 
Ghana Journal of Geography Vol. 13 (1), 2021 pages 147-166

percentage of observed data enveloped by the model whiles the r-factor as the thickness of the envelope. The uncertainty in the model output variables was expressed as a $95 \%$ prediction uncertainty (95PPU, known as the p-factor), which is calculated at the $2.5 \%$ and $97.5 \%$ levels of the cumulative distribution of an output variable (Yang et al., 2008). The p-factor ranges from 0 to 1 while the $r$-factor ranges from 0 to infinity.

In the Basin, the Model delineated 27 sub-basins and 463 HRUs. The calibration period was set from the period 1989 to 1994 and 1995-2000 was used as the validation period. Calibration was performed using SUFI 2 where Coefficient of determination $\left(\mathrm{R}^{2}\right)$ was set as the objective function type. The Coefficient of determination $\left(\mathrm{R}^{2}\right)$, Nash Sutcliffe (NS), Percentage Bias (PBIAS), and Root Mean Square Error (RMSE) was used to determine the Performance of the model.

\section{Data Analysis}

The simulation outputs were analysed and presented using Microsoft Excel 2010.

\section{Results}

\section{Model Calibration and Validation Performance}

The calibration and validation results are presented in Table 6. Overall, the model performed well in simulating the observed monthly discharge of the basin. For the calibration, an NS value of 0.76 and an $\mathrm{R}^{2}$ value of 0.84 (closer to 1 ) indicate good model performance. In addition, an RMSE value of 0.49 is acceptable. Similarly, the validation statistics indicated good model performance, with an RMSE value of 0.54 , NS value of 0.70 and $\mathrm{R}^{2}$ value of 0.77 . While the validation performance values are slightly lower than the calibration, the positive PBIAS values suggest an underestimation of the observed discharge data (Krause \& Boyle, 2005; Gassman et al., 2007; Arnold et al., 2012). The inability of the SWAT model to model higher flows has been reported by many researchers (Arnold et al., 2012; Khoi \& Thom, 2015; Abbas et al., 2016). The possible reasons could be incomplete soil and land use database or inaccurate GIS information, which has been a general concern of hydrological models (Wu and Chen, 2015). 
Table 6: Calibration and validation performance of SWAT.

\begin{tabular}{lll}
\hline & Calibration & Validation \\
Objective Function & $(1989-1994)$ & $(1995-2000)$ \\
\hline $\mathrm{R}^{2}$ & 0.84 & 0.77 \\
NS & 0.76 & 0.70 \\
PBIAS & $25.6 \%$ & $22.2 \%$ \\
RMSE & 0.49 & 0.54 \\
\hline
\end{tabular}

Note: $\mathrm{R}^{2}$ denotes the coefficient of determination, NS denotes Nash-Sutcliffe Efficiency, PBIAS denotes Percentage Bias and RMSE denotes Root Mean Square Error.

Source: Authors, 2019

\section{Future Climate Projections}

\section{Rainfall and Temperature}

In the 2050s, the mean annual rainfall is projected to increase by 20.05 and $21.37 \mathrm{~mm}$ over baseline value under the RCP 4.5 and RCP 8.5 scenarios, respectively (Table 7). For some months, however, reductions in mean rainfall were observed under both scenarios (Figure 4). These were February, July, September, and December. The largest reductions occurred in July (41.23 mm and $40.36 \mathrm{~mm}$ for RCP 4.5 and RCP 8.5, respectively) and September (28.08 mm and $33.44 \mathrm{~mm}$ for RCP 4.5 and RCP 8.5, respectively), with the least in December. Increases in mean annual minimum and maximum temperatures over baseline values were $1.28{ }^{\circ} \mathrm{C}$ to $1.49^{\circ} \mathrm{C}$, respectively, for RCP 4.5 , and $2.5^{\circ} \mathrm{C}$ to $2.7^{\circ} \mathrm{C}$, respectively for RCP 8.5 (Figure 4). Temperatures are expected to increase from March to June and August with temperatures of March recording the highest for both scenarios above the baseline temperature (Figure 4). The RCP 4.5 projects a drop $0.04{ }^{\circ} \mathrm{C}$ and $0.12{ }^{\circ} \mathrm{C}$ in maximum and minimum temperature, respectively, in September while maximum temperature in November drops slightly below the baseline. 


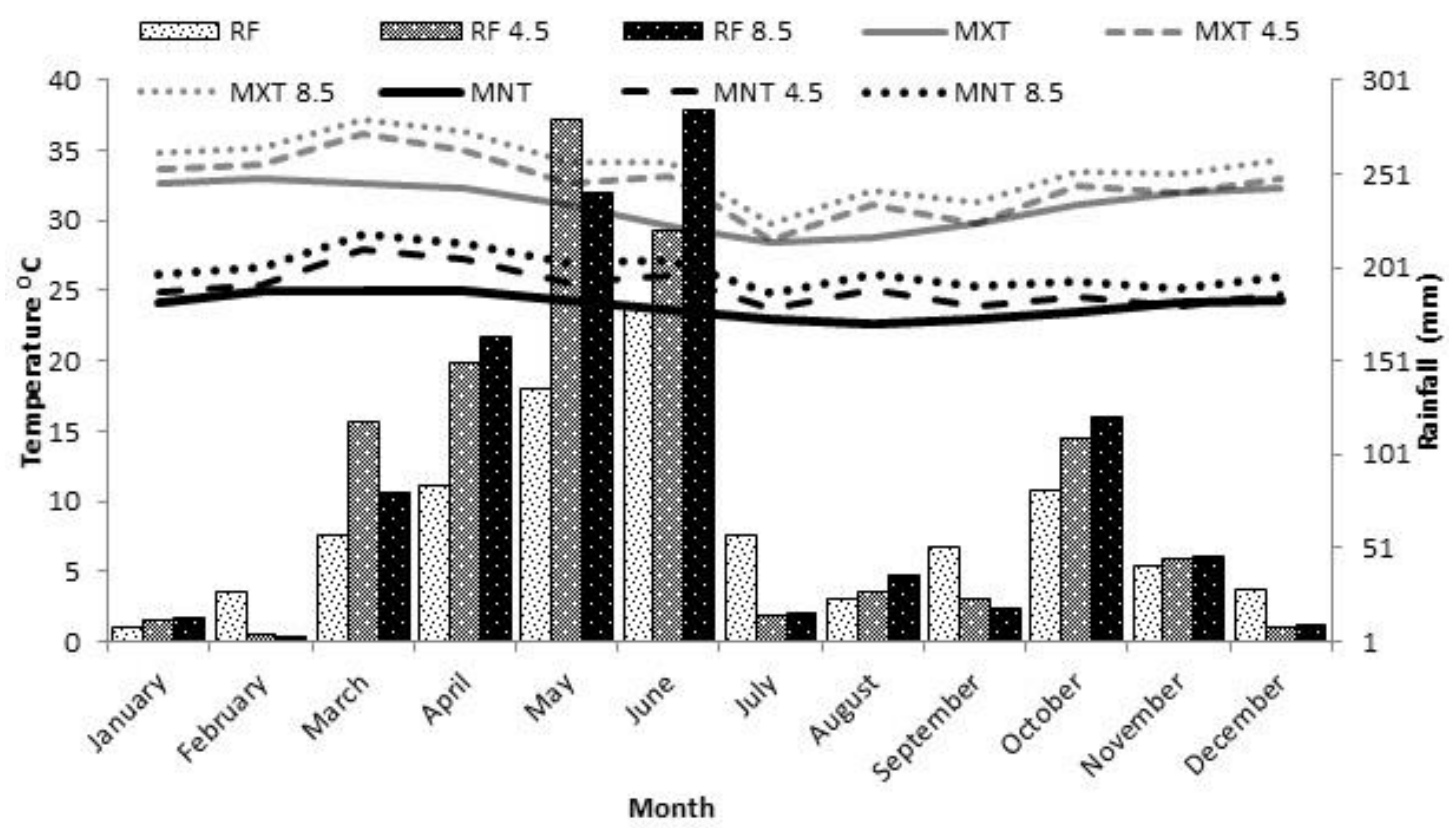

Figure 4: Mean monthly rainfall $(\mathrm{mm})$ and minimum and maximum temperature $\left({ }^{\circ} \mathrm{C}\right)$ for the climate change scenarios (RCP 4.5 and RCP 8.5 ) and the baseline period.

Source: Authors, 2019

Note: RF is baseline rainfall, RF4.5 is RCP 4.5 rainfall, RF8.5 is RCP 8.5 rainfall, MXT is baseline maximum temperature, MNT is baseline minimum temperature, MXT4.5 is RCP 4.5 maximum temperature, MNT4.5 is RCP 4.5 minimum temperature, MXT8.5 is RCP 8.5 maximum temperature and MNT8.5 is RCP 8.5 minimum temperature.

\section{Climate Change Impact on Hydrological Processes}

\section{Evapotranspiration (ET)}

The projected annual evapotranspiration (ET) over the DRB under both climate change scenarios shows about $60 \%$ increase above baseline ET (Table 7). Annually, an average increase in ET of $38.4 \mathrm{~mm}$ was observed for RCP 4.5 and RCP 8.5 scenarios. For both scenarios, a higher increase in ET is anticipated from March to June, with June recording 81.99 $\mathrm{mm}$ and $82.51 \mathrm{~mm}$, respectively (

Table 8). The ET is projected to decline from July to September.

\section{Soil Water Storage (SW)}

Under both RCP 4.5 and RCP 8.5 , annual average soil water storage (SW) is projected to increase by about $80 \mathrm{~mm}$ in the 2050s (Table 7). For both scenarios, May and June were the 
months with highest SW (130.9 mm and $109.7 \mathrm{~mm}$, respectively for RCP 4.5, and $122.6 \mathrm{~mm}$ and $118.1 \mathrm{~mm}$, respectively for RCP 8.5) (

Table 8).

\section{Water Yield (WY)}

A reduction of about $22.5 \mathrm{~mm}$ to $23.2 \mathrm{~mm}$ in annual WY is projected for the two climate change scenarios by the 2050s (Table 7). The highest reduction in WY was recorded in July with 47.5 $\mathrm{mm}$ and $48.9 \mathrm{~mm}$ respectively for RCP 4.5 and RCP 8.5. January and August are months, which recorded the lowest reductions of less than $6 \mathrm{~mm}$ (

Table 8).

Table 7: Annual mean difference between baseline and projected rainfall, evapotranspiration, soil water, water yield and temperature.

\begin{tabular}{|c|c|c|c|c|c|c|}
\hline & $\begin{array}{l}\text { Rainfall } \\
(\mathrm{mm})\end{array}$ & $\begin{array}{l}\text { Temperature }\left({ }^{\circ} \mathrm{C}\right) \\
\text { Minimum }\end{array}$ & $\begin{array}{l}\text { Temperature } \\
\left({ }^{\circ} \mathrm{C}\right) \text { maximum }\end{array}$ & $\begin{array}{l}\text { Evapotranspiration } \\
(\mathrm{mm})\end{array}$ & $\begin{array}{l}\text { Soil water } \\
(\mathrm{mm})\end{array}$ & $\begin{array}{l}\text { Water } \\
\text { yield } \\
(\mathrm{mm})\end{array}$ \\
\hline $\begin{array}{l}\text { RCP } \\
4.5\end{array}$ & 20.05 & 1.28 & 1.49 & 38.09 & 79.28 & -23.2 \\
\hline $\begin{array}{l}\text { RCP } \\
8.5\end{array}$ & 21.37 & 2.5 & 2.7 & 38.72 & 80.39 & -22.5 \\
\hline
\end{tabular}

Note: RCP 4.5 (Representative Concentration Pathways 4.5) and RCP 8.5 (Representative Concentration Pathways 8.5).

Source: Authors, 2019 
Ghana Journal of Geography Vol. 13 (1), 2021 pages 147-166

Table 8: Difference between projected (RCP 4.5 and RCP 8.5) monthly means of Evapotranspiration, Soil Water and Water Yield and baseline monthly means Evapotranspiration (mm)

\begin{tabular}{|c|c|c|c|c|c|c|c|c|c|c|c|c|}
\hline MONTH & January & February & March & April & May & June & July & August & September & October & November & December \\
\hline RCP 4.5 & 15.50 & 8.13 & 66.64 & 64.86 & 62.54 & 81.99 & 27.75 & 17.22 & 13.85 & 45.55 & 28.90 & 24.13 \\
\hline RCP 8.5 & 16.58 & 9.84 & 56.59 & 63.00 & 62.49 & 82.51 & 32.11 & 19.60 & 16.49 & 48.59 & 30.08 & 26.71 \\
\hline \multicolumn{13}{|c|}{ Soil Water (mm) } \\
\hline MONTH & January & February & March & April & May & June & July & August & September & October & November & December \\
\hline RCP 4.5 & 57.84 & 48.86 & 51.13 & 73.74 & 130.85 & 109.65 & 82.86 & 79.88 & 72.65 & 90.02 & 88.40 & 65.46 \\
\hline RCP 8.5 & 60.81 & 48.71 & 33.84 & 70.18 & 122.62 & 118.09 & 87.21 & 89.19 & 74.94 & 96.07 & 94.07 & 68.95 \\
\hline \multicolumn{13}{|c|}{ Water Yield (mm) } \\
\hline MONTH & January & February & March & April & May & June & July & August & September & October & November & December \\
\hline RCP 4.5 & -5.68 & -17.63 & -18.16 & -28.70 & -2.18 & -44.81 & -47.52 & -6.08 & -28.52 & -27.11 & -31.46 & -20.51 \\
\hline RCP 8.5 & -5.55 & -17.90 & -28.78 & -26.85 & -27.69 & -4.06 & -48.92 & -5.62 & -29.46 & -24.28 & -30.50 & -20.35 \\
\hline
\end{tabular}

Note: RCP 4.5 and RCP 8.5 (Representative Concentration Pathways 4.5 and Representative Concentration Pathways 8.5).

Source: Authors, 2019 


\section{Discussion}

\section{Projected Changes in Rainfall and Temperature}

The projected rainfall pattern from the CIMP5 data is typical of the basin and southern Ghana in general, with peak or highest rainfall in May-June (WRC, 2017). Generally, rainfall increases over the baseline values under both scenarios (RCP 4.5 and 8.5). However, substantial increases over baseline rainfall are observed in the months of April, May and June. In the other months, the differences are smaller, with baseline values exceeding projected values in the months of February, July, September, and December. These suggest a potential intensification of the dry season (November to March) over the basin. The results also suggest a concentration of rainfall from March to June (that could have implications for flooding) while sharp declines in the remaining months could worsen water availability if water demand increases in the future. Yankson et al. (2018) reported that Ghana is now witnessing a change in the rainfall system with longer dry seasons and a shortening wet season.

Simulation of future rainfall in West Africa is governed by uncertainties (Sultan \& Gaetani, 2016). Stanturf et al. (2011) predicted an increase of (2.65 $\pm 13.96 \%)$ rainfall in the wet season along the coastal savannah zone by 2050. The monthly increase and decrease in the rainfall amount observed in the current study have been reported in a similar study by Faramarzi et al. (2013), who also reported an overall increase in the rainfall in West Africa. In Ghana, Kasei \& Barnabas (2014) reported a decrease and highly variable rainfall amount in the future while WRC (2017) has reported that in the past decade the amount of rainfall at the Densu River Basin has reduced. The differences could be due to the different sources of future climate datasets. The current study is the first to use the CIMP5 data over the DRB. Generally, these differences underscore the uncertainty associated with projected rainfall and further sampling using weather generators for climate change studies (Yawson et al., 2016; Yawson, 2013).

\section{Impacts of Projected Climate Change on Hydrological Processes}

\section{Evapotranspiration}

One of the most important components of the hydrological cycle is evapotranspiration (ET), which is related to the energy exchanges in the atmosphere, ground surface and plant root zone. In the DRB, ET is a major hydrological control as it can account for as much as $77 \%$ of the annual rainfall in the basin (WRC, 2017). In the current study, ET increases over baseline values for all months, with largest increases for both scenarios occurring from March to June. 
Ghana Journal of Geography Vol. 13 (1), 2021 pages 147-166

It is this same period when rainfall is highest. Evaporative loss of water is mainly regulated by air temperature and availability of water in the evaporative surface (Mehan et al., 2016). Temperature over the basin does not vary substantially through the year (Figure 4). This suggests that availability of water in the presence of higher temperatures can explain the observed higher ET values in March to June. Thus, the projected increase in temperature can lead to an increased evaporative demand of the atmosphere, resulting in increased evapotranspiration in the Densu River Basin (Asante \& Amuakwa-Mensah, 2014; Trenberth et al., 2009). It is worth pointing out that other factors, such as land use/cover changes and other anthropogenic activities would also influence the scale of ET (Mehan et al., 2016). The DRB according to Yorke \& Margai, $(2007 ; 2014)$ and Ayivor \& Gordon (2012) is greatly affected by land use /cover conditions and anthropogenic activities such as land degradation through soil mining, wood harvest, conversion of forest to agriculture lands and agricultural lands into residential lands.

\section{Soil Water Storage and Water Yield}

Due to the increase in rainfall, especially from March to June, the amount of water stored in the soil profile of DRB increases over the baseline period (

Table 8). As expected, hydric soils within the basin have the capacity to store more water. As the main non-hydric soil type is sandy loam, infiltration could be high, resulting in large soil water storage in the underlying clay layers. It is noteworthy that the months with large soil water storage also have large ET, suggesting that soil water storage contributes to ET (Mehan et al., 2016) as soil water balance is a function of the interactions among rainfall, temperature and ET (Aguilera \& Murillo, 2009). Studies on groundwater discharge and soil moisture in DRB shows that about $14 \%$ of the annual rainfall is retained in soil (Tumbulto, 2005 and Adomako et al., 2010).

\section{Water Yield}

Water yield is the amount of water in runoff, lateral flow, groundwater contribution to the stream flow, less transmission losses through channels. In the current study, even though mean annual rainfall is expected to increase over baseline value, the water yield in the DRB is projected to decline over baseline levels by the 2050s ( 
Table 8). This could be due to greater than proportionate increase in ET over increases in rainfall. Higher temperature difference (Figure 4) and evapotranspiration occur around the months of high rainfall (March to June,

Table 8). The temperature changes around these months are, however, higher than the months within the dry season. Similar temperature differences around these months (March to June) have been projected by Stanturf et al. (2011) along the coastal savannah for 2050. Thus, warmer temperatures could drive ET in the presence of ample water supply, resulting in reduced water yield in the future (Dai et al. 2004).

The inconsistence between soil water storage and water yield could also be explained by the fact that hydric soils could absorb and retain large amount of water especially when being saturated from a dry state. In such a case, the soils do not contribute significantly to water yield due to resistance to flow, including matric forces (Dodds \& Whiles, 2010). In addition, it could be that the water holding capacity of the soils are not fully satisfied under current conditions. With increase in rainfall under future climate, the soils are able to satisfy their water holding capacity and perhaps release the water very slowly. According to Allan \& Castillo (2007), infiltration, percolation, lateral and vertical movement of water through the soil is influenced by the degree of soil saturation but the answer to the question, "how much water does the different type of soil needs to be saturated" remains unanswered for now.

The study did not consider drivers of climate change such as population growth, land cover changes, etc. The prediction of the future (2050s) hydrological components was based on the baseline land use and soil data. Changes in these can affect the projected hydrological processes. Hence, the results in the current study should be interpreted within the confines of these limitations.

\section{Conclusions}

The current study assessed the impacts of projected climate change on evapotranspiration, soil water storage and water yield of the Densu River Basin (DRB) in Ghana under two emissions scenarios (RCP 4.5 and 8.5) in the 2050s. Based on the CIMP5 datasets, the DRB is projected to have increased in the mean annual rainfall of about $20 \mathrm{~mm}$ compared to baseline values under both scenarios. However, the increase in rainfall is concentrated in the period April to June, with either similar or reduced rainfall in other months compared to the baseline. This has implications for both flood and drought in the DRB. Projected warmer temperatures will substantially increase evapotranspiration in the basin. As a result, even though soil water 
Ghana Journal of Geography Vol. 13 (1), 2021 pages 147-166

storage increases over baseline values, overall water yield is reduced compared to baseline values. As the DRB is used mainly for water supply in parts of the Greater Accra Region and irrigation in the basin, it is important to undertake further studies that can underpin adaptation planning. Based on the current study, measures to reduce unproductive loss of water in the basin will be prudent under both current and future conditions.

\section{References}

Abbas, T., Nabi, G., Boota, M. W., Hussain, F., Azam, M. I., Jin, H., \& Faisa, M. (2016). Uncertainty analysis of runoff and sedimentation in a forested watershed using sequential uncertainty fitting method. Sciences in Cold and Arid Regions, 8(4), 297-310.

Abbaspour, K. C., Van Genuchten, M. T., Schulin, R., \& Schläppi, E. (1997). A sequential uncertainty domain inverse procedure for estimating subsurface flow and transport parameters. Water Resources Research, 33(8), 1879-1892.

Adomako, D., Maloszewski, P., Stumpp, C., Osae, S., \& Akiti, T. T. (2010). Estimating groundwater recharge from water isotope $(\delta 2 \mathrm{H}, \delta 18 \mathrm{O})$ depth profiles in the Densu River basin, Ghana. Hydrological Sciences Journal-Journal des Sciences Hydrologiques, 55(8), 1405-1416

Aguilera, H., \& Murillo, J. M. (2009). The effect of possible climate change on natural groundwater recharge based on a simple model: A Study of four Karstic Aquifers in SE Spain. Environmental Geology, 57(5), 963-974.

Allan, J. D., \& Castillo, M. M. (2007). Stream ecology : structure and function of running waters. Springer.

Amoako, J., Karikari, A. Y., Ansa-Asare, O. D., \& Adu-Ofori, E. (2010). Water quality characteristics of Densu River basin in south-east Ghana. Water Science and Technology, 61(6), 1467-1477.

Arndt, C., Asante, F., Thurlow, J., \& Rosen, M. A. (2015). Implications of Climate Change for Modeling, 1-7. https://doi.org/10.3390/su7067214

Arnold, J. G., Kiniry, J. R., Srinivasan, R., Williams, J. R., Haney, E. B., \& Neitsch, S. L. (2013). Soil \& Water Assessment Tool: Input/output documentation. version 2012. Texas Water Resources Institute, TR-439, 650. Retrieved from http://swat.tamu.edu/media/69296/SWAT-IO-Documentation-2012.pdf

Arnold, J. G., Moriasi, D. N., Gassman, P. W., Abbaspour, K. C., White, M. J., Srinivasan, R., \& Jha, M. K. (2012). SWAT: Model Use, Calibration, and Validation. Transactions of the Asabe, 55(4), 1549-1559.

Asante, F., \& Amuakwa-Mensah, F. (2014). Climate Change and Variability in Ghana: Stocktaking. Climate, 3(1), 78-99.

Asante, K., Quarcoopome, T., \& Amevenku, F. (2008). Water Quality of the Weija Reservoir after 28 years of Impoundment. West African Journal of Applied Ecology, 13, 8. https://doi.org/10.4314/wajae.v13i1.40588

Ashiagbori, G., Forkuo, E. K., Laari, P., \& Aabeyir, R. (2014). Modelling Soil Erosion in the Densu River Basin Using RUSLE and GIS Tools. Journal of Environmental Science \& Engineering, 56(3), 247-254.

Asumadu-Sarkodie, S., Owusu, P. A., \& Rufangura, P. (2015). Impact analysis of flood in Accra, Ghana. Pelagia Research Library, 6(9), 53-78. Retrieved from www.pelagiaresearchlibrary.com 
Awotwi, A., Kumi, M., Jansson, P. E., Yeboah, F., \& Nti, I. K. (2015). Predicting hydrological response to climate change in the White Volta catchment, West Africa. Journal of Earth Science \& Climatic Change, 6(1), 1-7.

Ayivor, J. S., \& Gordon, C. (2012a). Impact of land use on river systems in Ghana. West African Journal of Applied Ecology, 20(3), 83-95.

Ayivor, J. S., \& Gordon, C. (2012b). Watershed disturbance and its potential effects on river systems in the Okyeman traditional area of Ghana: The case of Atewa Range Forest Reserve. West African Journal of Applied Ecology, 20(3), 97-108.

Dai, A., Trenberth, K. E., \& Qian, T. (2004). A Global Dataset of Palmer Drought Severity Index for 1870-2002: Relationship with Soil Moisture and Effects of Surface Warming. Journal of Hydrometeorology, 5(6), 1117-1130. https://doi.org/10.1175/JHM-386.1

Daily, G. (2003). What are ecosystem services. Global environmental challenges for the twenty-first century: Resources, consumption and sustainable solutions, 227-231.

Dodds, Walter K., \& Whiles, M. R. (2010). Freshwater ecology : concepts and environmental applications of limnology. Academic Press.

Faramarzi, M., Abbaspour, K. C., Ashraf V. S., Farzaneh, M. R., Zehnder, A. J. B., Srinivasan, R., \& Yang, H. (2013). Modeling impacts of climate change on freshwater availability in Africa. Journal of Hydrology, 480, 85-101.

Fianko, J. R. (2011). Health Risk Associated with Pesticide Contamination of Fish from the Densu River Basin in Ghana. Journal of Environmental Protection, 2(2), 115-123. https://doi.org/10.4236/jep.2011.22013

Gassman, P. W., Reyes, M. R., Green, C. H., \& Arnold, J. G. (2007). The soil and water assessment tool: Historical development, applications, and future research directions. Trans. Asabe, 50(4), 1211-1250.

GSS. (2012). 2010 Population and Housing Census: Final Results. Ghana Statistical Service. 2008.08.001 http://www.rmit.eblib.com.au/EBLWeb/patron 2012.12.016

IPCC. (2014a). Livelihoods and Poverty. Climate Change 2014: Impacts, Adaptation and Vulnerability. Part A: Global and Sectoral Aspects. Contribution of Working Group II to the Fifth Assessment Report of the InterGovernmental Panel on Climate Change, 793832. https://doi.org/10.1017

Kankam-Yeboah, K., Obuobie, E., Amisigo, B., \& Opoku-Ankomah, Y. (2013). Impact of climate change on streamflow in selected river basins in Ghana. Hydrological sciences journal, 58(4), 773-788.

Karikari, A. Y., \& Ansa-Asare, O. D. (2006). Physico-Chemical and Microbial Water Quality Assessment of Densu River of Ghana. West African Journal of Applied Ecology, 10(1), $1-12$.

Kasei, R. A., \& Barnabas, A. (2014). The Nexus of Changing Climate and Impacts on Rainfed Water Supply and Fresh Water Availability for the Inhabitants of Densu Basin and Parts of Accra - Ghana , West Africa. Journal of Environmental and Earth Science, 4(20), 8496.

Khoi, D. N., \& Thom, V. T. (2015). Parameter uncertainty analysis for simulating streamflow in a river catchment of Vietnam. Global Ecology and Conservation, 4, 538-548.

Krause, P., \& Boyle, D. P. (2005). Advances in Geosciences Comparison of different efficiency criteria for hydrological model assessment. Advances In Geosciences, 5(9), 89-97. https://doi.org/10.5194/adgeo-5-89-2005

Mehan, S., Kannan, N., Neupane, R. P., Mcdaniel, R., \& Kumar, S. (2016). Climate Change Impacts on the Hydrological Processes of a Small Agricultural Watershed. MDPI, 1-22. https://doi.org/10.3390/cli4040056

Mekonnen, M. M., \& Hoekstra, A. Y. (2016). Four billion people facing severe water 
scarcity. Science advances, 2(2), e1500323).

Neitsch, S. L., Arnold, J. G., Kiniry, J. R., \& Williams, J. R. (2011). Soil and Water Assessment Tool Theoretical Documentation Version 2009. Texas Water Resources Institute. https://doi.org/10.1016/j.scitotenv.2015.11.063

Owusu, K., Waylen, P., \& Qiu, Y. (2008). Changing rainfall inputs in the Volta basin: implications for water sharing in Ghana. GeoJournal, 71(4), 201-210. https://doi.org/10.1007/s10708-008-9156-6

Schuol, J., Abbaspour, K. C., Srinivasan, R., \& Yang, H. (2008). Estimation of freshwater availability in the West African sub-continent using the SWAT hydrologic model. Journal of Hydrology, 352(1-2), 30-49.https://doi.org/10.1016/j.jhydrol.2007.12.025

Shah, E., Liebrand, J., Vos, J., Veldwisch, G. J., \& Boelens, R. (2018). The UN Water and Development Report 2016 "Water and Jobs": A critical review. Development and Change, 49(2), 678-691.

Stanturf, J. A., Warren, M. L., Charnley, S., Polasky, S. C., Goodrick, S. L., Armah, F., \& Nyako, Y. A. (2011). Ghana climate change vulnerability and adaptation assessment. Washington: United States Agency for International Development.

Sultan, B., \& Gaetani, M. (2016). Agriculture in West Africa in the twenty-first century: climate change and impacts scenarios, and potential for adaptation. Frontiers in Plant Science, 7, 1262.

Tay, C., \& Kortatsi, B. (2008). Groundwater Quality Studies : A Case Study of the Densu Basin , Ghana. West African Journal of Applied Ecology, 12(1).

Trenberth, K. E., Fasullo, J. T., \& Kiehl, J. (2009). Earth's global energy budget. Bulletin of the American Meteorological Society, 90(3), 311-323.

Tumbulto, J. W. (2005). A study of water balance in the Pompon sub-catchment of the Densu River basin (Doctoral dissertation, Dissertation (PhD). Department of Geology, University of Ghana, Legon, Ghana).

Wallace, J. S. (2000). Increasing agricultural water use efficiency to meet future food production. Agriculture, ecosystems \& environment, 82(1-3), 105-119.

WRC. (2007). Densu River Basin - Integrated Water Resources Management Plan. http://www.wrc-gh.org/basins/

WRC. (2017). Densu Basin. Retrieved February 26, 2017, from http://www.wrcgh.org/basins/densu

Wu, H., \& Chen, B. (2015). Evaluating uncertainty estimates in distributed hydrological modeling for the Wenjing River watershed in China by GLUE, SUFI-2, and ParaSol methods. Ecological engineering, 76, 110-121.

Yang, J., Reichert, P., Abbaspour, K. C., Xia, J., \& Yang, H. (2008). Comparing uncertainty analysis techniques for a SWAT application to the Chaohe Basin in China. Journal of Hydrology, 358(1-2), 1-23.

Yawson, D.O., Ball, T., Adu, M.O., Mohan, S., Mulholland, B.J., White, P.J. (2016). Simulated regional yields of spring barley in the United Kingdom under projected climate change. Climate 4(54), 1 - 21.

Yawson, D.O. (2013). Climate Change and Virtual Water: Implications for UK Food Security. Ph.D. Thesis, University of Dundee, Dundee, UK.

Yorke, C., \& Margai, F. M. (2007). Monitoring land use change in the Densu River basin, Ghana: using GIS and remote sensing methods. African Geographical Review, 26, 87110.

Yorke, C., \& Margai, F. M. (2014). Monitoring Land Use Change in the Densu River Basin, Ghana Using GIS and Remote Sensing Methods. Igarss, (1), 1-5. 
APPENDICES: Annual and monthly descriptive statistics of observed hydro climate parameters for the baseline period (1986-2015)

\section{Rainfall (mm)}

\begin{tabular}{|c|c|c|c|c|c|c|c|c|c|c|c|c|c|}
\hline $\begin{array}{l}\text { Mon } \\
\text { th }\end{array}$ & $\begin{array}{l}\text { Janu } \\
\text { ary }\end{array}$ & $\begin{array}{l}\text { Febr } \\
\text { uary }\end{array}$ & $\begin{array}{l}\mathrm{Ma} \\
\mathrm{rch}\end{array}$ & $\begin{array}{l}\mathrm{Ap} \\
\text { ril }\end{array}$ & $\begin{array}{l}\text { Ma } \\
\text { y }\end{array}$ & $\begin{array}{l}\text { Jun } \\
\mathrm{e}\end{array}$ & $\begin{array}{l}\text { Jul } \\
y\end{array}$ & $\begin{array}{l}\text { Aug } \\
\text { ust }\end{array}$ & $\begin{array}{l}\text { Septe } \\
\text { mber }\end{array}$ & $\begin{array}{l}\text { Oct } \\
\text { ober }\end{array}$ & $\begin{array}{l}\text { Nove } \\
\text { mber }\end{array}$ & $\begin{array}{l}\text { Dece } \\
\text { mber }\end{array}$ & $\begin{array}{l}\text { Ann } \\
\text { ual }\end{array}$ \\
\hline $\begin{array}{l}\mathrm{ME} \\
\mathrm{AN}\end{array}$ & 9.6 & 26.8 & $\begin{array}{l}60 . \\
2\end{array}$ & $\begin{array}{l}90 . \\
9\end{array}$ & $\begin{array}{l}13 \\
7.9\end{array}$ & $\begin{array}{l}180 . \\
2\end{array}$ & $\begin{array}{l}56 . \\
6\end{array}$ & $\begin{array}{l}22 . \\
5\end{array}$ & 51.8 & 77.8 & 35.1 & 29.3 & 64.9 \\
\hline $\begin{array}{l}\text { MA } \\
X\end{array}$ & 47.2 & $\begin{array}{l}137 . \\
8\end{array}$ & $\begin{array}{l}213 \\
.9\end{array}$ & $\begin{array}{l}26 \\
9.4\end{array}$ & $\begin{array}{l}40 \\
3.8\end{array}$ & $\begin{array}{l}419 . \\
3\end{array}$ & $\begin{array}{l}18 \\
4.2\end{array}$ & $\begin{array}{l}118 \\
.1\end{array}$ & 151.4 & $\begin{array}{l}198 . \\
7\end{array}$ & 133.5 & 113.5 & $\begin{array}{l}419 . \\
3\end{array}$ \\
\hline MIN & 0 & 0 & 0 & 6.1 & $\begin{array}{l}16 . \\
6\end{array}$ & 35.9 & 0 & 0.2 & 7.5 & 2 & 0 & 5.7 & 0 \\
\hline STD & 11.3 & 34.8 & $\begin{array}{l}55 . \\
5\end{array}$ & $\begin{array}{l}59 . \\
5\end{array}$ & $\begin{array}{l}85 . \\
4\end{array}$ & 96.8 & $\begin{array}{l}41 . \\
4\end{array}$ & $\begin{array}{l}26 . \\
1\end{array}$ & 42.2 & 56.8 & 27.3 & 33.6 & 71.9 \\
\hline $\begin{array}{l}\text { TOT } \\
\text { AL }\end{array}$ & $\begin{array}{l}671 \\
0\end{array}$ & $\begin{array}{l}1877 \\
9\end{array}$ & $\begin{array}{l}422 \\
44\end{array}$ & $\begin{array}{l}63 \\
80 \\
1\end{array}$ & $\begin{array}{l}96 \\
79 \\
2\end{array}$ & $\begin{array}{l}126 \\
514\end{array}$ & $\begin{array}{l}39 \\
73 \\
9\end{array}$ & $\begin{array}{l}158 \\
11\end{array}$ & 36337 & $\begin{array}{l}546 \\
45\end{array}$ & 24629 & $\begin{array}{l}2055 \\
8\end{array}$ & $\begin{array}{l}546 \\
558\end{array}$ \\
\hline & & & & Eva & $\overline{\text { otr }}$ & pirat & on & & & & & & \\
\hline $\begin{array}{l}\text { Mon } \\
\text { th }\end{array}$ & $\begin{array}{l}\text { Janu } \\
\text { ary }\end{array}$ & $\begin{array}{l}\text { Febr } \\
\text { uary }\end{array}$ & $\begin{array}{l}\mathrm{Ma} \\
\mathrm{rch}\end{array}$ & $\begin{array}{l}\mathrm{Ap} \\
\text { ril }\end{array}$ & $\begin{array}{l}\mathrm{Ma} \\
\mathrm{y}\end{array}$ & $\begin{array}{l}\text { Jun } \\
\mathrm{e}\end{array}$ & $\begin{array}{l}\text { Jul } \\
y\end{array}$ & $\begin{array}{l}\text { Aug } \\
\text { ust }\end{array}$ & $\begin{array}{l}\text { Septe } \\
\text { mber }\end{array}$ & $\begin{array}{l}\text { Oct } \\
\text { ober }\end{array}$ & $\begin{array}{l}\text { Nove } \\
\text { mber }\end{array}$ & $\begin{array}{l}\text { Dece } \\
\text { mber }\end{array}$ & $\begin{array}{l}\text { Ann } \\
\text { ual }\end{array}$ \\
\hline $\begin{array}{l}\text { ME } \\
\text { AN }\end{array}$ & 19.4 & 20.3 & $\begin{array}{l}26 . \\
1\end{array}$ & $\begin{array}{l}29 . \\
9\end{array}$ & $\begin{array}{l}32 . \\
7\end{array}$ & 31.9 & $\begin{array}{l}20 . \\
8\end{array}$ & $\begin{array}{l}18 . \\
7\end{array}$ & 21.4 & 27.3 & 23 & 21.6 & 24.4 \\
\hline $\begin{array}{l}\text { MA } \\
X\end{array}$ & $\begin{array}{l}164 . \\
2\end{array}$ & $\begin{array}{l}164 . \\
9\end{array}$ & $\begin{array}{l}196 \\
.8\end{array}$ & $\begin{array}{l}19 \\
2.9\end{array}$ & $\begin{array}{l}18 \\
2.4\end{array}$ & $\begin{array}{l}154 . \\
9\end{array}$ & $\begin{array}{l}13 \\
0.6\end{array}$ & $\begin{array}{l}116 \\
.2\end{array}$ & 135.1 & $\begin{array}{l}172 . \\
4\end{array}$ & 155.9 & 173.1 & $\begin{array}{l}196 . \\
8\end{array}$ \\
\hline MIN & 2.7 & 2.7 & 1.9 & 6.5 & $\begin{array}{l}11 . \\
1\end{array}$ & 11.8 & 5.9 & 3.9 & 4.2 & 4.4 & 3.9 & 2.3 & 1.9 \\
\hline STD & 32.2 & 32.5 & $\begin{array}{l}34 . \\
3\end{array}$ & $\begin{array}{l}34 . \\
5\end{array}$ & $\begin{array}{l}30 . \\
6\end{array}$ & 23.9 & $\begin{array}{l}20 . \\
4\end{array}$ & $\begin{array}{l}20 . \\
7\end{array}$ & 22.6 & 30.1 & 29.6 & 31.3 & 29.3 \\
\hline TOT & 136 & 1424 & 183 & 21 & $\begin{array}{l}22 \\
91\end{array}$ & 220 & $\begin{array}{l}14 \\
62\end{array}$ & 131 & 14991 & 191 & 16170 & 1516 & 205 \\
\hline $\mathrm{AL}$ & 35 & 1 & 22 & 9 & 81 & 33 & & 02 & & 76 & & 0 & 388 \\
\hline
\end{tabular}




\section{Soil Water Storage (mm)}

\begin{tabular}{llllllllllllll}
\hline $\begin{array}{l}\text { Mon } \\
\text { th }\end{array}$ & $\begin{array}{l}\text { Janu } \\
\text { ary }\end{array}$ & $\begin{array}{l}\text { Febr } \\
\text { uary }\end{array}$ & $\begin{array}{l}\text { Ma } \\
\text { rch }\end{array}$ & $\begin{array}{l}\text { Ap } \\
\text { ril }\end{array}$ & $\begin{array}{l}\text { Ma } \\
\text { y }\end{array}$ & $\begin{array}{l}\text { Jun } \\
\text { e }\end{array}$ & $\begin{array}{l}\text { Jul } \\
\text { y }\end{array}$ & $\begin{array}{l}\text { Aug } \\
\text { ust }\end{array}$ & $\begin{array}{l}\text { Septe } \\
\text { mber }\end{array}$ & $\begin{array}{l}\text { Oct } \\
\text { ober }\end{array}$ & $\begin{array}{l}\text { Nove } \\
\text { mber }\end{array}$ & $\begin{array}{l}\text { Dece } \\
\text { mber }\end{array}$ & $\begin{array}{l}\text { Ann } \\
\text { ual }\end{array}$ \\
\hline ME & 53.8 & 51.8 & 52. & 54. & 61. & 69.1 & 68. & 65. & 66.3 & 64.9 & 61.4 & 57.9 & 60.7 \\
AN & & & 8 & 8 & 4 & & 7 & 5 & & & & & \\
MA & 792. & 788. & 789 & 79 & 81 & 819. & 83 & 823 & & 814. & & & 834. \\
X & 1 & 3 & .6 & 1.4 & 0.5 & 1 & 4.9 & .7 & & 3 & & & 9 \\
MIN & 3.1 & 1.4 & 3.5 & 4.5 & 7.2 & 7.5 & 9.3 & 7.3 & 8.8 & 6.7 & 6.1 & 4 & 1.4 \\
STD & 153. & 153. & 153 & 15 & 15 & 153. & 15 & 153 & & 153. & & & 153.3 \\
& 3 & 3 & .3 & 3.4 & 3.5 & 7 & 3.7 & .5 & 153.4 & 3 & & 153.3 & 4 \\
TOT & 377 & 3637 & 370 & 38 & 43 & & 48 & & & & & & 4 \\
AL & 71 & 3 & 80 & 48 & 07 & 485 & 22 & 459 & 46559 & 455 & 43129 & 6068 & 511 \\
& & & & 0 & 4 & & 7 & & & 50 & & 6 & 378
\end{tabular}

\section{Water Yield (mm)}

\begin{tabular}{|c|c|c|c|c|c|c|c|c|c|c|c|c|c|}
\hline $\begin{array}{l}\text { Mon } \\
\text { th }\end{array}$ & $\begin{array}{l}\text { Janu } \\
\text { ary }\end{array}$ & $\begin{array}{l}\text { Febr } \\
\text { uary }\end{array}$ & $\begin{array}{l}\text { Ma } \\
\text { rch }\end{array}$ & $\begin{array}{l}\text { Ap } \\
\text { ril }\end{array}$ & $\begin{array}{l}\text { Ma } \\
\mathrm{y}\end{array}$ & $\begin{array}{l}\text { Jun } \\
\mathrm{e}\end{array}$ & $\begin{array}{l}\text { Jul } \\
\mathrm{y}\end{array}$ & $\begin{array}{l}\text { Aug } \\
\text { ust }\end{array}$ & $\begin{array}{l}\text { Septe } \\
\text { mber }\end{array}$ & $\begin{array}{l}\text { Oct } \\
\text { ober }\end{array}$ & $\begin{array}{l}\text { Nove } \\
\text { mber }\end{array}$ & $\begin{array}{l}\text { Dece } \\
\text { mber }\end{array}$ & $\begin{array}{l}\text { Ann } \\
\text { ual }\end{array}$ \\
\hline $\begin{array}{l}\text { ME } \\
\text { AN }\end{array}$ & 7.6 & 18.2 & $\begin{array}{l}41 . \\
1\end{array}$ & $\begin{array}{l}63 . \\
5\end{array}$ & $\begin{array}{l}10 \\
1.2\end{array}$ & $\begin{array}{l}153 . \\
9\end{array}$ & $\begin{array}{l}59 . \\
1\end{array}$ & $\begin{array}{l}15 . \\
2\end{array}$ & 32.5 & 57.4 & 38.9 & 21.8 & 50.9 \\
\hline $\begin{array}{l}\text { MA } \\
X\end{array}$ & 47.7 & $\begin{array}{l}101 . \\
9\end{array}$ & $\begin{array}{l}188 \\
.4\end{array}$ & $\begin{array}{l}20 \\
9.1\end{array}$ & $\begin{array}{l}29 \\
9.3\end{array}$ & $\begin{array}{l}392 . \\
8\end{array}$ & $\begin{array}{l}17 \\
7\end{array}$ & 77 & 121.4 & $\begin{array}{l}181 . \\
4\end{array}$ & 157.4 & 71.7 & $\begin{array}{l}392 . \\
8\end{array}$ \\
\hline MIN & 0 & 0 & 0.2 & 2.9 & 7.5 & 33.7 & 7 & 0.3 & 2.1 & 3.7 & 0.1 & 0 & 0 \\
\hline STD & 11.3 & 25.6 & $\begin{array}{l}40 . \\
7\end{array}$ & $\begin{array}{l}45 . \\
9\end{array}$ & $\begin{array}{l}59 . \\
3\end{array}$ & 89.8 & $\begin{array}{l}40 . \\
2\end{array}$ & $\begin{array}{l}18 . \\
7\end{array}$ & 32.5 & 46.1 & 34.8 & 22.6 & 59.2 \\
\hline $\begin{array}{l}\text { TOT } \\
\text { AL }\end{array}$ & $\begin{array}{l}536 \\
3\end{array}$ & $\begin{array}{l}1275 \\
2\end{array}$ & $\begin{array}{l}288 \\
48\end{array}$ & $\begin{array}{l}44 \\
60 \\
1\end{array}$ & $\begin{array}{l}71 \\
00 \\
5\end{array}$ & $\begin{array}{l}108 \\
002\end{array}$ & $\begin{array}{l}41 \\
51 \\
5\end{array}$ & $\begin{array}{l}106 \\
37\end{array}$ & 22826 & $\begin{array}{l}403 \\
19\end{array}$ & 27323 & $\begin{array}{l}1531 \\
0\end{array}$ & $\begin{array}{l}428 \\
500\end{array}$ \\
\hline
\end{tabular}

